\title{
THE EFFECT OF IRON NUTRITIONAL STATUS ON TRYPANOSOMA CRUZI INFECTION IN GERMFREE AND CONVENTIONAL MICE
}

\author{
Maria L. Pedrosa, ${ }^{*}$ Jacques R. Nicoli,$\dagger$ Marcelo E. Silva, $\ddagger$ Marcio E. Silva, $\dagger$ \\ Marcílio E. C. Silva, † Leda Q. Vieira,† Eduardo A. Bambirra $\S$ and Enio C. Vieira†\| \\ *Departamento de Ciências Biológicas, Instituto de Ciências Exatas e Biológicas, Universidade Federal \\ de Ouro Preto, Ouro Preto, MG, Brazil; †Laboratório de Gnotobiologia, Departamento de Bioquímica \\ e Imunologia, Instituto de Ciências Biológicas, Universidade Federal de Minas Gerais, C.P. 2486, \\ 30161-960 Belo Horizonte, MG, Brazil (Fax: 55-31-441-5963); †Departamento de Nutrição, Universidade \\ Federal de Ouro Preto, Ouro Preto, MG, Brazil; §Departamento de Anatomia Patológica, Faculdade de \\ Medicina, Universidade Federal de Minas Gerais, Belo Horizonte, MG, Brazil
}

(Received 12 January 1993; accepted 17 February 1993)

\begin{abstract}
Conventional (CV) and gnotobiotic (GN) female CFW mice were infected with the Y strain of Trypanosoma cruzi.

2. After infection, both $\mathrm{CV}$ and $\mathrm{GN}$ groups received injections of iron-dextran or desferrioxamine. Non-injected mice served as controls.

3. The parasitemia was more intense in iron-dextran-treated mice.

4. The iron levels in serum, liver, and spleen were: (a) not decreased by desferrioxamine and (b) increased by iron-dextran treatments.

5. An increase in leukocyte numbers was observed in all GN and $\mathrm{CV}$ groups after infection.

6. There was no difference in total iron binding capacity (TIBC) and iron saturation transferrin (IST) between $\mathrm{GN}$ and $\mathrm{CV}$ mice before infection.

7. In CV groups, after infection, TIBC was decreased whereas the levels of IST were increased; in GN the opposite occurred.

8. Trypanosome-specific IgG and IgM antibody levels were raised in the GN group but not in the CV group.
\end{abstract}

\section{INTRODUCTION}

The nutritional status of the host may affect its relationship with the parasite (Keusch and Farthing, 1986). Iron, among other specific nutrients, plays an important role in the pathogenesis of many diseases. Some evidence favors the hypothesis that mild iron deficiency would limit the proliferation of the pathogen thus protecting the host against infection. On the other hand, some authors suggest that iron deficiency would predispose the host to infection by interfering with the immune system (Weinberg, 1984, 1990; Kent et al., 1990).

The course of experimental infection with $T$. cruzi is affected by nutritional factors. In a series of papers in the 1960s, Yaeger and Miller studied the effect of deficiencies of thiamine, pantothenate, pyridoxine, vitamin $A$, protein and zinc on the evolution of American trypanosomiasis in rats. Those papers were reviewed by Scrimshaw et al. (1968).

Recently, a relative protection against infection with $T$. cruzi in mice submitted to essential fatty acid deficiency was reported (Santos et al., 1992). Almeida et al. (1989) showed that the mortality index was higher in animals either deficient or overloaded with

\|To whom correspondence should be addressed. vitamin $\mathrm{E}$ as compared to controls fed on a diet containing normal levels of $\alpha$-tocopherol.

In relation to iron nutriture, an increase in the cellular iron stocks through administration of irondextran led to higher mortality in mice infected with the Brazil strain of Trypanosoma cruzi; administration of desferrioxamine with the consequent decrease of iron stores led to a reduction of pathogenicity (Lalonde and Holbein, 1984). Results from this laboratory showed that treatment of mice with iron-dextran and further infection with $T$. cruzi resulted in: (1) higher parasitemia and mortality with the Y strain; (2) more pronounced parasitemia with the CL strain; (3) no effect with the YuYu strain. Treatment with desferrioxamine led to: (1) milder disease with the YuYu strain; (2) no effect with the $\mathrm{Y}$ and CL strains (Pedrosa et al., 1990a).

The germfree (GF) animal is a good model for studies of the host-parasite relationship. The lack of any antigenic challenge by living organisms allows a specific response to any invading agent. American trypanosomiasis is much more severe in GF than in conventional (CV) mice and rats (Silva et al., 1987) whereas cutaneous leishmaniasis is much more severe in CV mice (Vieira et al., 1987).

In the present work, the effects of iron deprivation and supplementation in $\mathrm{CV}$ and GF mice infected 
with the Y strain of $T$. cruzi were evaluated through the determination of parasitological, biochemical, hematological, immunological and histopathological parameters. A preliminary report of this work has been published (Pedrosa et al., 1990b).

\section{MATERIALS AND METHODS}

\section{Mice}

CV and GF CFW 60-day-old female mice were housed in flexible plastic isolators (Trexler, 1959), handled according to established procedures (Pleasants, 1974) and fed on a commercial diet (Nuvilab, Nuvital, PR, Brazil). The animals were derived from a breeding nucleus of GF mice kindly supplied by $\mathrm{Dr}$ Morris Pollard (Lobund Laboratory, University of Notre Dame, U.S.A.). The CV animals used were derived from the GF colony after many generations in an open animal room.

\section{Parasites}

T. cruzi, Y strain, was maintained by successive transfers in CFW mice. The infection was carried out as described previously (Silva et al., 1987).

\section{Parasitemia}

Mice were bled daily from the tail, starting at the 5th day after infection, for the evaluation of the number of circulating parasites, according to Brener (1962).

\section{Assays}

The number of red blood cells and total leukocytes were evaluated. Serum iron and total iron-binding capacity (TIBC) were determined with a commercial kit (Labtest, Belo Horizonte, MG, Brazil) based on the method of Goodwin et al. (1966). Spleen and liver iron levels were determined by the phenanthroline method after incineration according to AOAC (1980). Iron saturation transferrin (IST) was determined from the ratio: serum iron/TBIC.

\section{$\operatorname{Ig} G$ and $\operatorname{Ig} M$ determination}

Trypanosome-specific antibodies in serum samples were identified by an enzyme-linked immunosorbent assay (ELISA) in which the antigen was $4.0 \times 10^{4}$ clean epimastigotes, kindly provided by Centro de Pesquisas René Rachou, Fundação Oswaldo Cruz, Belo Horizonte, MG, Brazil. The parasites were fixed to the ELISA plate (Hemobag, Campinas, SP, Brazil) by drying a suspension of cells in carbonate/bicarbonate buffer, $\mathrm{pH} 9.6$, onto the wells. The wells were blocked with bovine serum albumin (Biobrás, Montes Claros, MG, Brazil). Horseradish peroxidase conjugated goat anti-mice immunoglobulins (Sigma, St. Louis, MO, U.S.A.) served as conjugate and the peroxidase substrate was $o$-phenylenediamine. The procedure followed was that described by McLaren et al. (1980). Optical absorbance was read at $492 \mathrm{~nm}$ with an ELISAreader.

\section{Experimental design}

Eighty $\mathrm{CV}$ and $50 \mathrm{GF}$ female mice were inoculated with 1700 blood forms of $T$. cruzi. The infected animals were divided into three groups. One group remained as controls. The remaining two groups were injected intraperitoneally either with $5 \mathrm{mg}$ of irondextran (ferric hydroxide dextran complex, Sigma) or with $10 \mathrm{mg}$ of desferrioxamine mesithylate (Desferal, Ciba, Brazil) on days 5 and 6 after infection. These drugs were previously filter-sterilized and introduced into the isolators in sealed ampoules. On days 6, 10 and 15 after infection, some of the animals from all groups were weighed and killed under ether anesthesia. Blood was collected from the axillary plexus. Liver and spleen were removed and weighed. Fragments of these organs were used for iron assays and the remaining of the viscera and carcass were used for histopathological evaluation.

\section{Histopathological examination}

Tissue samples were fixed in $4 \%$ formaldehyde and processed for paraffin embedding. The histological sections $(3-5 \mu \mathrm{m})$ were stained with hematoxylineosin and the slides examined by only one person who did not have access to the codification of the animal, whose identification was done only after each report had already been written.

\section{Statistical analysis}

The results were compared through analysis of variance followed by the determination of the minimal significant difference (Snedecor and Cochran, 1980). The calculations were made using the EPISTAT computer program (T.L. Gustafson, Round Rock, TX, U.S.A.).

\section{RESULTS}

Effect of treatment with iron-dexiran or desferrioxam ine on parasitemia and histopathology

Parasitemia in CV and in gnotobiotic (GN) mice (i.e. monoassociated with $T$. cruzi) are shown in Fig. 1. Control animals showed detectable parasitemia from day 7 of infection and peak parasitemia occurred on day 9. Parasitemia on both $\mathrm{GN}$ and $\mathrm{CV}$ mice was intensified when these animals were treated with iron-dextran. These results suggest that the increase in iron availability stimulates the proliferation of $T$. cruzi in $\mathrm{GN}$ and $\mathrm{CV}$ mice. The parasitemia of both $\mathrm{CV}$ or GN mice treated with desferrioxamine did not differ from the non-treated control group.

On histopathological examination, no difference between iron-dextran or desferrioxamine-treated mice and their controls could be detected, either in $\mathrm{CV}$ or GN animals. However, the disease was more severe in $\mathrm{GN}$ than in $\mathrm{CV}$ mice as revealed by a more 


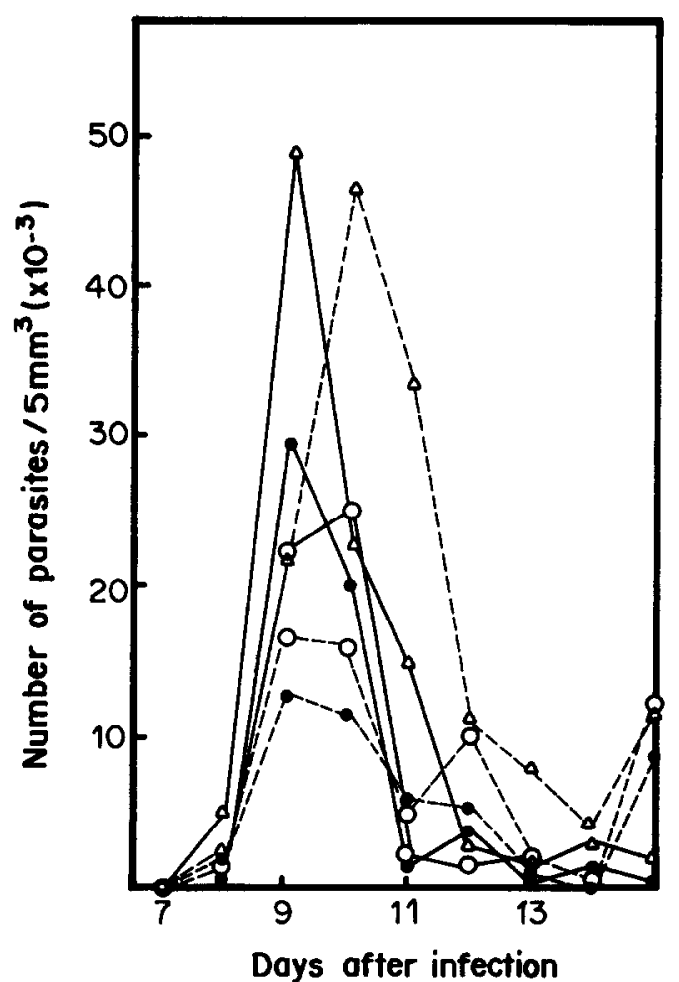

Fig. 1. Parasitemia in control $(O)$, desferrioxamine-treated $(O)$, and iron-dextran-treated $(\Delta)$ conventional $(-)$ and gnotobiotic (-- ) mice inoculated with 1700 Trypanosoma cruzi (blood forms). No. of animals: from 7 to 10 day, 10-14 and 9-10; from day 11 to $15,4-8$ and $4-6$ for conventional and gnotobiotic mice, respectively.

intense cell and tissue parasitism, confirming previous results (Silva et al., 1987).

Effect of desferrioxamine or iron-dextran on the iron status of the host after infection with $\mathrm{T}$. cruzi

The effect of the treatments with desferrioxamine and iron-dextran on serum levels of iron of infected animals were evaluated (Fig. 2A). CV and GN animals treated with desferrioxamine did not show significant differences on serum iron when compared with untreated controls at the same day after infection. Treatment of $\mathrm{CV}$ animals with iron-dextran slightly elevated the levels of serum iron; this increase was only detected on day 15 post-infection. In GN animals the levels of iron were higher in dextrantreated mice than in controls reaching a maximum on day 6 post-infection.

Before infection and on day 6 after inoculation with $T$. cruzi, the iron content in liver of GF controls was higher than of their CV counterparts. Desferrioxamine-treated GN mice showed lower levels of iron in liver than GN controls 10 days after infection but not on day 15 when there was an increase in the iron levels. No such alterations were observed in the CV group. Treatment with iron-dextran enhanced the levels of iron in livers of $\mathrm{GN}$ and $\mathrm{CV}$ infected mice (Fig. 2B) on days 15 and 10 after infection, respectively.

The iron contents in spleen are shown in Fig. 2C. Before infection these contents were the same in $\mathrm{CV}$ and GF animals. After infection, these levels were significantly raised in $\mathrm{CV}$ but not in GN mice. Treatment with desferrioxamine did not produce any alteration in iron levels when compared to infected controls, both for CV and GN mice. On treatment with iron-dextran, there was an elevation of iron levels in spleens on day 15 after infection in $\mathrm{CV}$ mice and on days 10 and 15 in GN mice.

Effect of the infection with $\mathrm{T}$. cruzi on serum iron, total iron binding capacity $(T I B C)$, and iron saturation transferrin (IST)

Table 1 shows that the levels of serum iron, TIBC and IST were the same in GF and CV controls before infection. In the course of the disease, serum iron levels were not altered in the CV group; however, in GN mice a rise in this parameter was observed. In the CV group, TIBC levels were decreased 15 days after infection whereas IST levels increased after day 10 of infection. In GN animals, TIBC increased sharply after 10 day of infection and the IST decreased at day 15 .

\section{Effect of the infection with $\mathrm{T}$. cruzi on the levels of $\operatorname{IgG}$ and $\operatorname{Ig} M$}

The evolution of antibody levels in each group is shown in Fig. 3. The basal levels of antibodies were the same for both GN and CV groups. After infection, the levels of these immunoglobulins were significantly raised in the GN group, this did not occur in the CV group. When compared with their CV counterparts, the GN mice had higher titers of IgG and IgM, 15 days after infection.

Effect of desferrioxamine, iron-dextran and the infection with Trypanosoma cruzi on the number of red blood cells and leukocytes

Infection by $T$. cruzi caused a reduction in numbers of red blood cells in CV control mice, 15 days after infection (Table 2). This difference was not observed in animals treated with desferrioxamine or irondextran. There was an earlier and more intense reduction of the red blood cell number in control GN mice. Desferrioxamine- or iron-dextran-treated GN animals also showed a marked reduction in red blood cell number in the course of infection.

Table 3 shows the evolution of blood leukocytes in the different groups of animals. After infection, a rise in leukocyte number could be observed in all GN and CV mice. This rise in leukocyte number was less intense in GN mice when compared with their CV counterparts, with the exception of GF controls at day 15 after infection. 


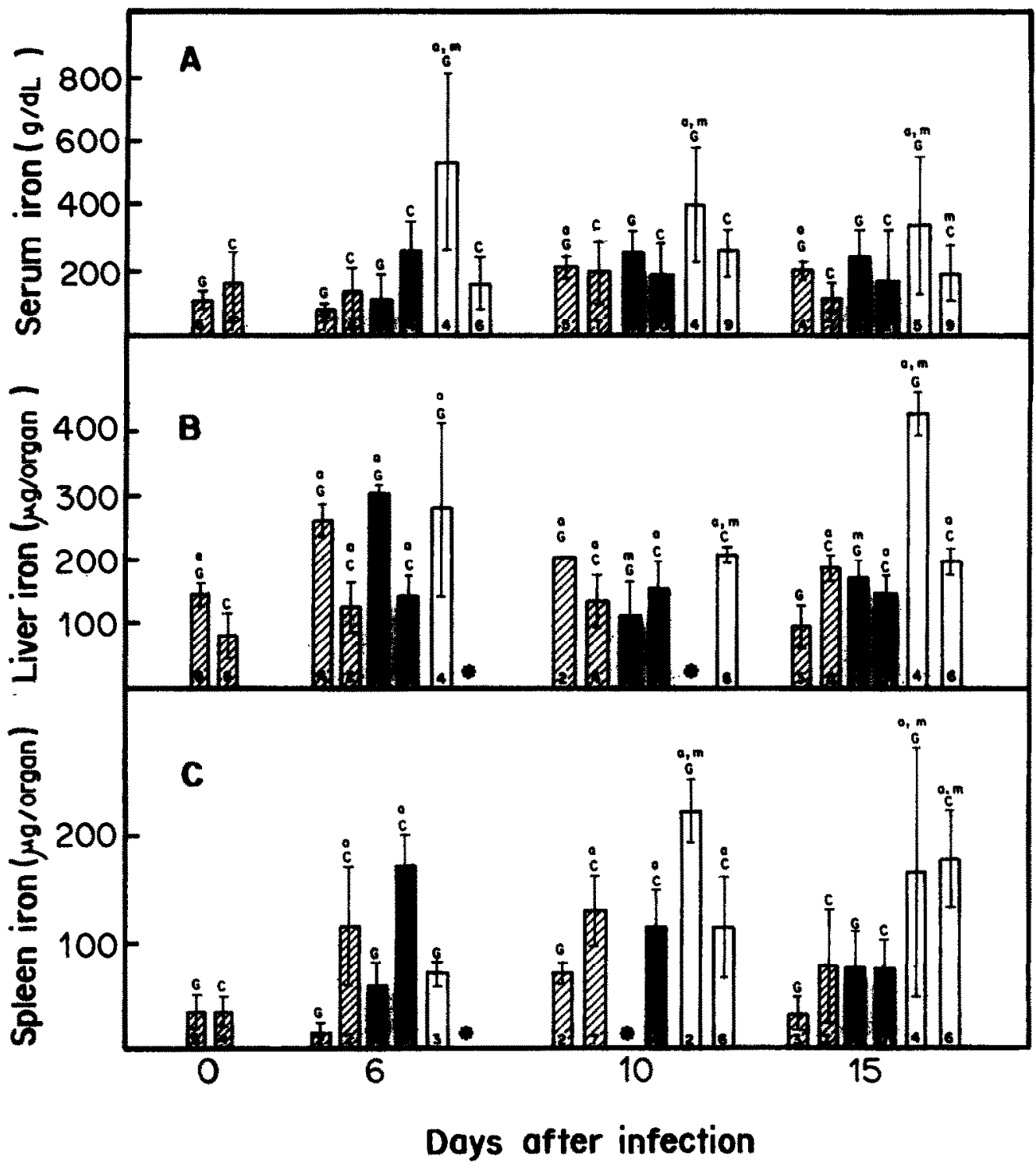

Fig. 2. Mean levels of iron in serum ( $\mu \mathrm{g} / \mathrm{d}$ ) $(\mathrm{A})$, liver ( $\mu \mathrm{g} /$ organ) $(\mathrm{B})$, and spleen $(\mu \mathrm{g} /$ organ) (C) in gnotobiotic $(G)$ and conventional $(C)$ control $(\mathbb{Q})$, desferrioxamine-treated $(\boldsymbol{G})$ or iron-dextran-treated mice $(\square)$. Assays were performed before infection or on days 6,10, and 15 after infection. Statistical differences $(P<0.05)$ are indicated as follows: $a$, in relation to day 0 within the same group; $e$, in relation to their conventional counterpart at day $0 ; \mathrm{m}$, in relation to their control counterpart at the same day of infection. The number of animals in each group are inside the vertical bar. Vertical lines represent the standard deviations of the means. ${ }^{*}$ Not done.

\section{Discussion}

Our results demonstrate that an increase in available iron stimulates the parasitemia in $\mathrm{CV}$ and $\mathrm{GN}$ mice (Fig. 1), confirming previous results (Pedrosa et al., 1990b). However, the higher rate of proliferation of the parasite with the increase in iron levels was not followed by a more intense tissue parasitism. The short period of experimentation could explain this apparent paradox.

Non-infected GF and CV mice presented the same values for serum iron and TIBC confirming the results obtained by Donati $e t$ al. (1969). After infection with $T$. cruzi, the levels of serum iron were not altered and increased in $\mathrm{CV}$ and $\mathrm{GN}$ animals, respectively (Table 1). However, TIBC levels were reduced and elevated in CV and GN mice, respectively, in the course of infection. Therefore, there is a difference in iron metabolism between GN and $\mathrm{CV}$ animals. It is known that $T$. cruzi is capable of suppressing the host immune system during the acute phase of the infection (Kierzenbaum and Sztein, 1990) what would lead to a reduction in transferrin synthesis by lymphocytes. This immunosuppression might not have occurred in 
Table 1. Levels of serum iron, total iron binding capacity (TIBC) and transferrin saturation index (TSI) in conventional (CV) and gnotobiotic (GN) mice infected with 1700 blood forms of Trypanosoma cruzi, Y strain

\begin{tabular}{|c|c|c|c|c|}
\hline Group & $\begin{array}{l}\text { Days after } \\
\text { infection }\end{array}$ & $\begin{array}{l}\text { Serum iron } \\
(\mu \mathrm{g} / \mathrm{dI})\end{array}$ & $\begin{array}{l}\text { TIBC } \\
(\mu \mathrm{g} / \mathrm{dl})\end{array}$ & $\begin{array}{l}\text { TSI } \\
(\%)\end{array}$ \\
\hline $\mathrm{CV}$ & 0 & $155.7 \pm 93.9$ & $\begin{array}{c}378.3 \pm 84.9 \\
(6)\end{array}$ & $33.0 \pm 16.2$ \\
\hline $\mathrm{CV}$ & 6 & $132.3 \pm 60.1$ & $309.3 \pm \frac{1}{(3)} 122.7$ & $43.3 \pm 23.8$ \\
\hline $\mathrm{CV}$ & 10 & $\begin{array}{c}183.9 \pm 89.9 \\
(7)\end{array}$ & $\underset{(4)}{294.3 \pm 152.7}$ & $72.8 \pm 14.4^{a}$ \\
\hline $\mathrm{CV}$ & 15 & $102.6 \pm \frac{45.8}{(7)}$ & $199.1 \pm \frac{ \pm}{(7)}$ & $52.7 \pm 14.6^{\mathrm{a}}$ \\
\hline GN & 0 & $104.8 \pm 22.2$ & $\begin{array}{c}318.3 \pm 97.6 \\
(6)\end{array}$ & $\underset{(6)}{35.8 \pm 14.0}$ \\
\hline GN & 6 & $\frac{73.8 \pm 10.9}{(7)}$ & $272.0 \pm 35.8$ & $28.5 \pm 4.5$ \\
\hline GN & 10 & $205.1 \pm 34.5^{2}$ & $\begin{array}{l}545.3 \pm 55.9^{a, e} \\
(4)\end{array}$ & $\begin{array}{l}36.0 \pm 4.7^{c} \\
(4)\end{array}$ \\
\hline GN & 15 & $202.9 \pm 39.9^{a, c}$ & $\frac{1129.0 \pm 218.0^{2, e}}{(4)}$ & $\begin{array}{l}18.5 \pm 4.0^{\mathrm{a}, e} \\
(4)\end{array}$ \\
\hline
\end{tabular}

GN mice. Therefore, these lymphocytes became more reactive and synthesized more transferrin.

Differences in the immune response between GN and CV animals were earlier reported by Rogers and Balish (1978): when CV and GF rats were infected with Candida albicans and later challenged with phytohemagglutinin and concanavalin $\mathbf{A}$, they observed: (1) suppression of splenocyte response in CV rat; (2) a five-fold increase in blastogenesis in GN rat. These results suggest that disseminated candidiasis is capable of suppressing blastogenesis in $\mathrm{CV}$ rat. The absence of antigenic stimuli derived from intestinal microbial flora could affect the immune response to infection with $T$. cruzi. Such differences may be evidenced by observing the levels of $T$. cruzi-antigen bound IgG and IgM in $\mathrm{CV}$ and $\mathrm{GN}$ mice. The levels of immunoglobulins in the latter were higher than in the former at day 15 after infection (Fig. 3). The GN group, therefore, produced more IgG and IgM than their CV counterparts. Higher titers of immunoglobulins were observed in GN rats infected with $T$. lewisi (Giannini, 1987) and in GN mice infected with T. cruzi (Furarah et al., 1991) than in their CV counterparts. This confirms the hypothesis that the difference in levels of TIBC between CV and GN mice may be due to differences in immunological responses.

Desferrioxamine, an iron chelator, has been widely used to evaluate the relationship between infection and iron nutriture (Duhr et al., 1989). Two mechanisms are proposed for its action: (1) induction of iron deficiency by limiting its availability within the cell, (2) direct interference with the acquisition of iron by the parasite (Hershko and Peto, 1988). In vitro, this chelating agent is able to remove iron from ferritin, hemosiderin and, to some extent, from transferrin (Keberle, 1964). Desferrioxamine did not affect the levels of liver, spleen and serum iron in cither $\mathrm{CV}$ or GN mice after infection with $T$. cruzi (Fig. 2), except for GN mice at day 10 after infection. Desferrioxamine did not affect the parasitemia (Fig. 1). These results confirm the ones previously obtained with the $\mathrm{Y}$ strain in $\mathrm{CV}$ mice even though this strain was more sensitive to iron deficiency (Pedrosa et al., 1990a). Pedrosa et al. (1990a) also reported that $\mathbf{4 0}$ days after infection, there was a decrease in the levels of iron in spleen and liver of desferrioxamine-treated mice. It is possible that the removal of iron by the chelating agent may be occurring after the period of high proliferation of the parasite which explains the results presented here.

In iron-dextran treated $\mathrm{CV}$ mice, there was a slight increase in the levels of serum iron, only detectable on day 15 after the infection. In GN mice, higher levels could be observed after day 6 of infection and remained high up to day 15 . Holbein (1980) investigated the destination of iron in mice after intraperitoneal injection of iron-dextran. Two hours later, the levels of serum iron reached its maximum. Histochemical examination of liver and spleen revealed that iron was deposited in cells of the reticuloendothelial system (Holbein, 1980). It may be concluded that the rise in serum iron in these animals is due to the drug. Our results show that dextran treatment promoted a rise in serum iron in GN mice 


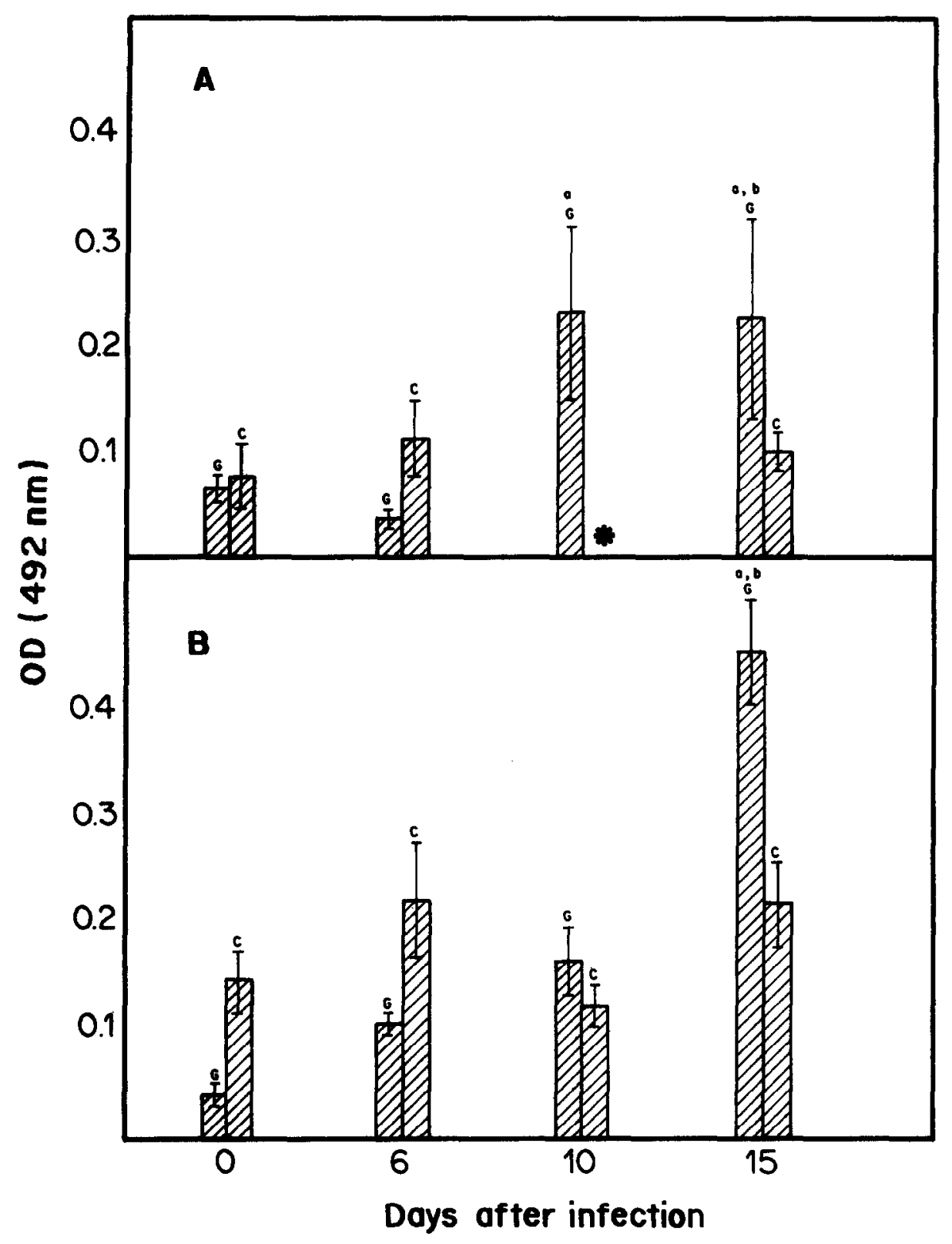

Fig. 3. Mean levels of IgM (A) and IgG (B) determined by ELISA in control gnotobiotic (G) and conventional $(C)$ mice. Assays were performed before infection and on days 6,10 and 15 after infection. Each bar represents an average of three to six samples. Statistical differences $(P<0.05)$ are indicated as follows: $a$, in relation to day 0 within the same group; $b$, in relation to the conventional counterpart at the same day of infection. Vertical lines represent the standard error of the means. *Not done.

(Table 1). It seems, therefore, that the uptake of iron from iron-dextran is more efficient in GN than in CV animals after intraperitoneal injection. On the other hand, the removal of serum iron by the reticuloendothelial system seems to be less efficient in the former group of animals. This corroborates the data of Donati et al. (1969) who observed that the clearance of radio-iron from plasma was markedly slower in the GF mouse, suggestive of a direct or indirect effect of the flora on the reticulo-endothelial system which could explain the difference in serum iron levels between GN and CV mice. Treatment with irondextran promoted an elevation of the levels of spleen iron in $\mathrm{CV}$ and $\mathrm{GN}$ mice, 15 and 10 days after the infection, respectively (Fig. 2C). An increase in liver iron content in both groups was also observed (Fig. 2B). The increase in iron content in these organs positively affected the proliferation of the parasites (Fig. 1).

No significant difference was found between $\mathrm{CV}$ and GN animals as far as blood red cell count is concerned. After infection, there was a reduction in erythrocyte 
Table 2. Number of red blood cells $/ \mathrm{mm}^{3}$ in conventional (CV) and gnotobiotic (GN) mice treated with desferrioxamine (D), iron dextran (F) or control groups (C)

\begin{tabular}{|c|c|c|c|c|}
\hline \multirow[b]{2}{*}{ Group } & \multicolumn{4}{|c|}{ Days after infection } \\
\hline & 0 & 6 & 10 & 15 \\
\hline $\mathrm{CV}-\mathrm{C}$ & $\begin{array}{c}1590 \pm 147 \\
(5)\end{array}$ & $1183 \pm \underset{(5)}{956}$ & $1280 \pm \frac{(5)}{540}$ & $1090 \pm 448^{a}$ \\
\hline CV-D & & $1605 \underset{(4)}{ \pm} 174$ & $1429 \pm \frac{231}{(5)}$ & $1147 \underset{(4)}{ \pm} 120$ \\
\hline CV-F & & $1137 \underset{(5)}{ \pm} 461$ & $\underset{(4)}{1562 \pm 319}$ & $1365 \underset{(4)}{ \pm 171}$ \\
\hline GN-C & $1772 \pm 225$ & $\begin{array}{l}949 \pm 350^{a, c} \\
(7)\end{array}$ & $\begin{array}{l}684 \pm 133^{4, c} \\
(5)\end{array}$ & $\begin{array}{l}619 \pm 268^{a, c} \\
\text { (4) }\end{array}$ \\
\hline GN-D & & ${ }_{(5)}^{1040 \pm 91^{\mathrm{a}, e}}$ & $\begin{array}{c}613 \pm 184^{a, e} \\
(6)\end{array}$ & $\begin{array}{l}456 \pm 268^{2, e} \\
(5)\end{array}$ \\
\hline GN-F & & $1521 \pm 556$ & $\begin{array}{l}949 \pm 316^{a, c} \\
\quad(4)\end{array}$ & $521 \pm 159^{\mathrm{a}, \mathrm{e}}$ \\
\hline
\end{tabular}

numbers in both groups (Table 2). Transitory hematological alterations have been described in various infections with trypanosomes which have been attributed to different factors: hemodilution, bone marrow injury, destruction of red blood cells and alteration of their turnover (Cardoso and Brener, 1980). In iron dextran-treated $G N$ mice, a reduction in the number of red blood cells was observed after day 10 of infection. In control and desferrioxamine-treated GN mice the red blood cell numbers were altered after day 6 of infection. A marked anemia in the GN group could be explained by the findings of Hashimoto and
Hashimoto (1968) who observed a smaller hematopoietic activity in GN than in the CV rat. Furthermore, the low IST in GN mice may have contributed to the decrease of the red blood cell count in these animals as compared with their CV counterparts.

An elevation of the number of leukocytes was observed in all $\mathrm{CV}$ and GN groups as infection progressed (Table 3). These results contradict the ones obtained by Cardoso and Brener (1980) who reported leukopenia in CV albino mice infected with $10^{4}$ trypomastigotes. This discrepancy may be explained by the different inoculum size or by the difference

Table 3. Number of leukocytes $/ \mathrm{mm}^{3} \times 10^{-3}$ of blood in conventional (CV) and gnotobiotic (GN) control mice (C) or in mice treated with desferrioxamine (D) or iron dextran $(\mathbf{F})$

\begin{tabular}{lcccc}
\hline & \multicolumn{4}{c}{ Days after infection } \\
\cline { 2 - 5 } Group & 0 & 6 & 10 & 12 \\
\hline CV-C & $8.26 \pm 2.12$ & $22.6 \pm 0.8^{\mathrm{a}}$ & $37.1 \pm 15.7^{\mathrm{a}}$ & $35.4 \pm 4.1^{\mathrm{a}}$ \\
& $(5)$ & $(5)$ & $(5)$ & $(4)$ \\
CV-D & & $35.2 \pm 14.5^{\mathrm{a}}$ & $34.5 \pm 13.0^{\mathrm{a}}$ & $56.4 \pm 9.5^{\mathrm{a}}$ \\
& & $(5)$ & $(5)$ & $(3)$ \\
CF-F & & $25.3 \pm 17.9^{\mathrm{a}}$ & $51.9 \pm 22.4^{\mathrm{a}, \mathrm{m}}$ & $54.8 \pm 4.5^{\mathrm{a}, \mathrm{m}}$ \\
& & $(5)$ & $(5)$ & $(4)$ \\
GN-C & $4.6 \pm 1.7^{\mathrm{c}}$ & $6.3 \pm 2.4^{\mathrm{e}}$ & $12.2 \pm 3.8^{\mathrm{a}, \mathrm{e}}$ & $33.5 \pm 8.3^{\mathrm{a}}$ \\
GN-D & $(\mathrm{)}$ & $(7)$ & $(5)$ & $(4)$ \\
& & $16.2 \pm 4.9^{\mathrm{a}}$ & $10.8 \pm 3.4^{\mathrm{a}}$ & $13.3 \pm 3.5^{\mathrm{a}, \mathrm{m}}$ \\
GN-F & & $(5)$ & $(5)$ & $(5)$ \\
& & $6.4 \pm 1.5$ & $17.3 \pm 7.0^{\mathrm{a}}$ & $20.0 \pm 6.6^{\mathrm{a}, \mathrm{m}}$ \\
\hline
\end{tabular}

Assays were performed before infection with 1700 blood forms of Trypanosoma cruzi, $Y$ strain, or on days 6,10 and 15 after infection

Statistical differences $(P<0.05)$ are indicated as superscripts; a, in relation to day 0 within the same group; $e$, non-infected $G N$ in relation to the $C V$ counterpart on the same day; $m$, in relation to the control counterpart on the same day. The number of mice is indicated in parentheses. 
in mice strains. In GN control, desferrioxamineand iron-dextran-treated mice, the rise in leukocyte number was less pronounced that in their $\mathrm{CV}$ counterparts, except for the GN control group on day 15 after infection. Anosa and Kaneko (1983) reported leukocytosis with lymphocytosis, monocytosis, eosinopenia and basophilia in $T$. bruce $i$-infected mice. One may suppose that in GN mice, the leukocyte proliferation occurs at a slower rate. On day 15 after infection the levels of leukocytes in GN mice reached the ones of $\mathrm{CV}$ animals but treatment with desferrioxamine or iron-dextran hindered this recovery. In CV mice there was a rise in leukocyte numbers from 3- to 7 -fold in all groups.

We have shown that GN mice differ from their $\mathrm{CV}$ counterparts in: (1) their response to infection by $T$. cruzi, (2) iron metabolism in different conditions of iron nutriture and (3) red blood cell and leukocyte numbers. These results demonstrate that, under the conditions described, desferrioxamine was not capable of producing alterations in the iron status of both GN and CV mice, and therefore, did not interfere with the uptake of iron by $T$. cruzi. Iron-dextran, on the other hand, did elevate the levels of iron in the host and, therefore, its availability, what facilitated the proliferation of the parasite.

Acknowledgements - This work was supported by Financiadora de Estudos e Projetos (FINEP), Conselho Nacional de Desenvolvimento Científico e Tecnológico (CNPq), Fundação de Amparo à Pesquisa do Estado de Minas Gerais (FAPEMIG), and Pró-Reitoria de Pesquisa da Universidade Federal de Minas Gerais (PRPQ-UFMG). The authors are greatly indebted to Ronilda Maria de Paula and Maria Cristina Leão Monteiro de Barros for skilful technical help.

\section{REFERENCES}

Almeida M. R., Silva M. E., Soares F. M. L. and Vieira E. C. (1989) Influence of vitamin $E$ nutriture on the evolution of Chagas' disease in mice. Mem. Inst. Oswaldo Cruz 84 (Suppl. II), 28.

Anosa V. O. and Kaneko J. J. (1983) Pathogenesis of Trypanosoma brucei infection in deer mice (Peromyscus maniculatus): hematologic, erythrocyte biochemical, and iron metabolic aspects. Am. J. vet. Res. 44, 639-644.

A.O.A.C. (Association of Official Analytical Chemists) (1980) Official Methods of Analyses (Edited by Horowitz E.), 13th Edn. Association of Official Analytical Chemists, Washington, DC.

Brener Z. (1962) Therapeutic activity and criterion of cure on mice experimentally infected with Trypanosoma cruzi. Rev. Inst. Med. Trop. São Paulo 4, 380-396.

Cardoso J. E. and Brener Z. (1980) Hematological changes in mice experimentally infected with Trypanosoma cruzi. Mem. Inst. Oswaldo Cruz 75, 97-104.

Dhur A., Galan P. and Hercberg S. (1989) Iron status, immune capacity and resistance to infections. Comp. Biochem. Physiol. 94A, 11-19.

Donati R. M., McLaughlin M. M., Levri E. A., Berman A. R. and Stromberg L. W. R. (1969) The response of iron metabolism to the microbial flora: studies on germfree mice. Proc. Soc. exp. biol. Med. 130, 920-922.

Furarah A. M., Crocco-Afonso L. C., Silva Marcelo E., Silva Márcio E., Silva M. E. C., Nicoli J. R., Vieria E. C. and Bambirra E. A. (1991) Immune responses in germfree and conventional mice infected with Trypanosoma cruzi. Braz. J. med. biol. Res. 24, 1223-31.

Giannini M. S. H. (1987) The specific anti-parasite immune responses of germ-free and conventional rats infected with Trypanosoma lewisi. J. Parasitol. 73, 144-148.

Goodwin J. F., Murphy B. and Guillemette M. (1966) Direct measurement of serum iron and binding capacity. Clin. Chem. 12, 47-57.

Hashimoto M. and Hashimoto N. (1968) Histological study of bone marrow in breeding rats. In Advances in Germfree Research and Gnotobiology (Edited by Miyakawa M. and Luckey T. D.), pp. 149-161, Illife Books, London.

Hershko C. and Peto T. E. A. (1988) Deferoxamine inhibition of malaria is independent of host iron status. J.exp. Med. 168, 375-387.

Holbein B. E. (1980) Iron-controlled infection with Neisseria meningitidis in mice. Infect. Immun. 29, 886891.

Keberle H. (1964) The biochemistry of desferrioxamine and its relation to iron metabolism. Ann. N.Y. Acad. Sci. 119, 758-768.

Kent S., Weinberg E. D. and Stuart-MacAdam P. (1990) Dietary and prophylactic iron supplements: helpful and harmful. Human Nature 1, 55-81.

Keusch G. T. and Farthing M. J. G. (1986) Nutrition and infection. Ann. Rev. Nutr. 6, 131-154.

Kierzenbaum F. and Sztein M. B. (1990) Mechanisms underlying immunosuppression induced by Trypanosoma cruzi. Parasitol. Today 6, 261-263.

Lalonde R. G. and Holbein B. E. (1984) Role of iron in Trypanosoma cruzi infection of mice. J. clin. Invest. $\mathbf{7 3}$, $470-476$

McLaren M. L., Lillywhite J. E. and Sirr S. (1980) $A$ Laboratory Method for IFAT and ELISA. The Ross Institute of Tropical Hygiene, London School of Hygiene and Tropical Medicine, London.

Pedrosa M. L., Silva Marcelo E., Silva Márcio E., Silva M. E. C., Nicoli J. R. and Vieria E. C. (1990a) The effect of iron deficiency and iron overload on the evolution of Chagas' disease produced by three strains of Try. panosoma cruzi in CFW mice. Comp. Biochem. Physiol. 97A, 235-243

Pedrosa M. L., Silva M. E., Silva M. E., Silva M. E. C., Vieria L. Q., Vieira E. C. and Bambirra E. A. (1990b) The effect of iron nutritonal status on experimental Chagas' disease in conventional and germfree mice. Microecol. Ther. 20, 453-457.

Pleasants, J. R. (1974). Gnotobiotics. In Handbook of Laboratory Animal Science (Edited by Melby, Jr. E. C. and Altman N. H.), pp. 119-174. CRC Press, Cleveland.

Rogers T. J. and Balish E. (1978) Effect of systemic candidiasis on blastogenesis of lymphocytes from germfree and conventional rats. Infect. Immun. 20, 142-150.

Santos C. F., Silva M. E., Evangelista E. A., Nicoli J. R., Santos J. E., Bambirra E. A. and Vieira E. C. (1992) Effect of an essential fatty acid deficient diet on experimental infection with Trypanosoma cruzi in germfree and conventional mice. Braz. J, med. biol. Res. 25, 795-803.

Scrimshaw N. S., Taylor C. E. and Gordon J. E. (1968) Interactions of Nutrition and Infection. World Health Organization, Geneva.

Silva M. E., Evangelista E. A., Nicoli J. R., Bambirra E. A. and Vieira E. C. (1987) American trypanosomiasis (Chagas' disease) in conventional and germfree rats and mice. Rev. Inst. Med. Trop. São Paulo 29, 284-288. 
Snedecor G. W. and Cochran W. G. (1980) Statistical Methods, pp. 215-237. New York University Press, New York.

Trexler P. C. (1959) The use of plastics in the design of isolator sytems. Ann. N.Y. Acad. Sci. 78, 29-36.

Vieira E. C., Nicoli J. R., Moraes-Santos T., Silva M. E., Costa C. A., Mayrink W. and Bambirra E. A. (1987)
Cutaneous leishmaniasis in germfree, gnotobiotic, and conventional mice. Rev. Inst. Med. Trop. São Paulo 29, 385-387.

Weinberg E. D. (1984) Iron withholding: a defense against infection and neoplasia. Physiol. Rev. 64, 65-102.

Weinberg E. D. (1990) Cellular iron metabolism in health and disease. Drug Metab. Rev. 22, 531-560. 